\title{
Nitrogen efficiency indexes for evaluating nitrogen uptake and use in ornamental bromeliad's root system and tank
}

\author{
Karina Gonçalves da Silva(1), Mauricio Lamano Ferreira ${ }^{(2)}$, Emerson Alves da Silva(1), \\ Shoey Kanashiro(1), Plínio Barbosa de Camargo( ${ }^{(3)}$ and Armando Reis Tavares ${ }^{(1)}$
}

\begin{abstract}
(1)Instituto de Botânica, Avenida Miguel Stéfano, no 3.687, Vila Água Funda, CEP 04301-902 São Paulo, SP, Brazil. E-mail: karina.gs.bio@gmail.com, easilva2004@yahoo.com.br, skanashi@uol.com.br, atavares2005@yahoo.com.br (2)Universidade Nove de Julho, Avenida Dr. Adolfo Pinto, no 109, Barra Funda, CEP 01156-050 São Paulo, SP, Brazil. E-mail: mauecoloia@yahoo.com.br (3)Universidade de São Paulo, Centro de Energia Nuclear na Agricultura, Avenida Centenário, oo 303, São Dimas, CEP 13416-000 Piracicaba, SP, Brazil. E-mail: pcamargo@cena.usp.br
\end{abstract}

\begin{abstract}
The objective of this work was to evaluate if nitrogen use efficiency (NUE) indexes can elucidate functional differences in nutrient uptake between the root system and tank of epiphytic bromeliads. The bromeliads Guzmania lingulata and Vriesea 'Harmony' received fertilizers in their tanks or through their roots using modified Hoagland \& Arnon solution, with 0.00 , 2.62, or $5.34 \mathrm{mmol} \mathrm{L}^{-1}$ nitrogen, as urea. After 90 days, nitrogen contents in leaves and plant biomass were evaluated, and NUE indexes were calculated. Guzmania lingulata and $V$. 'Harmony' fertilized in their tanks with $5.34 \mathrm{mmol} \mathrm{L}^{-1}$ had the highest averages of nitrogen uptake efficiency and recovery efficiency; those fertilized with $2.62 \mathrm{mmol} \mathrm{L}^{-1}$ through their roots showed the highest averages of NUE, nitrogen utilization efficiency, nitrogen physiological efficiency, and biomass conversion efficiency. The NUE indexes, besides being an effective tool to assess the nutritional status of ornamental bromeliads, reveal that the root system of epiphytic bromeliads is functional for nitrogen uptake and use.
\end{abstract}

Index terms: Guzmania lingulata, Vriesea, Bromeliaceae, nutritional efficiency index, plant nutrition, root functionality.

\section{Índices de eficiência do nitrogênio para avaliação da absorção e da utilização de nitrogênio no sistema radicular e no tanque de bromélias ornamentais}

\begin{abstract}
Resumo - O objetivo deste trabalho foi avaliar se os índices de eficiência de uso do nitrogênio (EUN) podem elucidar diferenças funcionais na absorção de nutrientes entre o sistema radicular e o tanque de bromélias epifíticas. As bromélias Guzmania lingulata e Vriesea 'Harmony' receberam fertilizantes nos seus tanques ou pelas raízes com solução de Hoagland \& Arnon modificada, com 0,00, 2,62 ou 5,34 $\mathrm{mmol} \mathrm{L}^{-1}$ de nitrogênio na forma de ureia. Após 90 dias, o conteúdo de nitrogênio nas folhas e a biomassa das plantas foram avaliados, e os índices de EUN calculados. Guzmania lingulata e $V$. 'Harmony' adubadas no tanque com 5,34 $\mathrm{mmol} \mathrm{L}^{-1}$ apresentaram maiores médias de eficiência de absorção de nitrogênio e de eficiência de recuperação; as adubadas nas raízes, com 2,62 $\mathrm{mmol} \mathrm{L}^{-1}$, apresentaram as maiores médias de EUN, eficiência de utilização de nitrogênio, eficiência fisiológica de nitrogênio e índice de eficiência de conversão de biomassa. Os índices de EUN, além de serem importantes ferramentas para avaliação do status nutricional das bromélias, revelam que o sistema radicular das bromélias epífitas é funcional para absorção e utilização de nitrogênio.
\end{abstract}

Termos para indexação: Guzmania lingulata, Vriesea, Bromeliaceae, índice de eficiência nutricional, nutrição de plantas, funcionalidade das raízes.

\section{Introduction}

The morphological and physiological diversity found in bromeliad species allows this plant group to occupy a wide range of habitats. These varying characteristics and growth habits determine the uptake and utilization of nutrients by these plants, which have adapted to the low and intermittent nutrient supply available in the epiphytic habitat (Lüttge, 2010; Gonçalves et al., 2016). The leaves of epiphytic bromeliads with tanks - a natural container formed by the imbrication of leaves have a high capacity to uptake nutrients, as nitrogen (Benzing \& Renfrow, 1974; Winkler \& Zotz, 2009; Leroy et al., 2013).

Nutrient uptake by epiphytic bromeliads, however, remains controversial. Some studies have reported 
the nonfunctionality of the plant's root system, with consequent transference of the uptake function to the leaf trichomes in the plant tank, reinforcing the basis of vegetative reduction in Bromeliaceae (Benzing \& Ott, 1981; North et al., 2013; Benzing, 2015). Other anatomical studies on the roots of bromeliads have shown the presence of velamen, which is an important structure associated with water and nutrient uptake through a passive movement in the roots; this structure is present in several taxa of epiphytic monocotyledonous families, such as Orchidaceae, Bromeliaceae, and Araceae, representing an example of convergent evolution (Silva \& Scatena, 2011; Dettke \& MilanezeGutierre, 2008; Males, 2016). The observed functional division between roots (plant anchorage) and tank (nutrient and water uptake) explains the different cultivation systems adopted for bromeliads.

The fertilization of ornamental bromeliads is based on plant habit; for example, the terrestrial and tank bromeliad Nidularium innocentii Lem. is fertilized through its roots, while the epiphytic bromeliad Vriesea incurvata Gaudich. is fertilized in its tank (Anacleto \& Negrelle, 2013). As a result of these different cultivation practices, no consensus has been reached as to the contribution of either tank or root system to nutrient uptake by bromeliads.

Nitrogen is fundamental for biological processes in plants, which has aroused interest in understanding and increasing the efficiency in its use by plants, reducing losses to the environment (Kant et al., 2011; Franklin et al., 2017). The main source of nitrogen for epiphytic tank bromeliads is organic nitrogen, such as amino acids (Takahashi \& Mercier, 2011) or urea (Giampaoli et al., 2017).

Nitrogen uptake can be assessed by nutritional efficiency indexes, which reflect physiological processes such as nitrogen uptake, efficiency of nitrate reduction, as well as nitrogen remobilization, translocation, assimilation, use, and storage (Fageria, 2009). Therefore, nitrogen use efficiency (NUE) is an important tool to evaluate the nutritional status of plants, since the different parameters used to calculate it allow to compare and determine genotypes that make the best use of applied nutrients. It is also possible to improve management techniques to enhance plant production and vegetative growth (Baligar et al., 2001; Dovale et al., 2012). Based on NUE results, the application of nitrogenous nutrients can be improved and, consequently, prevent the overuse of fertilizers, besides decreasing production costs and environmental damages (Hirel et al., 2011; Laufer et al., 2016). Furthermore, NUE expresses the relationship between plant production and applied inputs. The index is based on two major components: nitrogen uptake efficiency, which indicates the amount of nutrients absorbed per mass unit of dry roots; and nitrogen utilization efficiency, the nitrogen fraction obtained by the plant for conversion to total biomass. Nitrogen utilization efficiency is obtained by the ratio between nitrogen physiological efficiency and recovery efficiency; the first expresses the organic production, determined by the amount of accumulated nutrient, and the second, sometimes termed as nutrient acquisition efficiency, is the accumulative amount of nutrient in plants per unit of applied nutrient. Another important index is the biomass conversion efficiency, which expresses the amount of dry matter mass of shoots produced per unit of nutrient in the shoots (Baligar et al., 2001; Fageria, 2009; Xu et al., 2012).

Since these indexes are interconnected, their joint analysis can provide an integrated assessment of biomass accumulation efficiency from the available forms and concentrations of nitrogen supplied to plants.

The objective of this work was to evaluate if NUE indexes can elucidate functional differences in nutrient uptake between the root system and tank of epiphytic bromeliads.

\section{Materials and Methods}

Approximately six-months-old exemplars of commercial varieties of Guzmania lingulata Mez (initial measurements: 19.10 leaves, $37.40 \mathrm{~g}$ total fresh matter mass, $5.13 \mathrm{~g}$ total dry matter mass, and $7.37 \%$ foliar nitrogen; $\mathrm{n}=10$ ) and Vriesea 'Harmony' (initial measurements: 20.90 leaves, $56.70 \mathrm{~g}$ total fresh matter mass, $7.09 \mathrm{~g}$ total dry matter mass, and $7.12 \%$ foliar nitrogen; $\mathrm{n}=10$ ) were cultivated in $1.25-\mathrm{L}$ plastic containers, with pine bark as substrate (Table 1).

The experiment was conducted in a greenhouse, at Instituto de Botânica, located in São Paulo, in the state of São Paulo, Brazil. The plants were fertilized twice a week with $20 \mathrm{~mL}$ HA solution no. 2 (Hoagland \& Arnon, 1950), modified with $0.00,2.62$, or 5.34 mmol L-1 nitrogen, supplied directly on the substrate 
or in the plant tanks. The $\mathrm{pH}$ of the solutions was adjusted to 5.8. The plant tanks were drained before fertilization to avoid the rundown of solution from the tanks to the substrate.

The experiment was carried out for 90 days, and, subsequently, the plants were removed from the containers, cleaned, and separated into roots and shoots, which were dried in a forced-air oven at $45^{\circ} \mathrm{C}$ until reaching constant weight. Samples were subjected to sulfuric acid digestion and then to the semi-micro Kjeldahl method for total $\mathrm{N}$ analysis.

Nitrogen efficiency indexes were calculated as follows: nitrogen use efficiency, NUE $\left(\mathrm{g} \mathrm{g}^{-1}\right)=$ total plant dry mass/applied nitrogen (Xu et al., 2012); nitrogen uptake efficiency, $\mathrm{NUpE}\left(\mathrm{g} \mathrm{g}^{-1}\right)=$ nitrogen uptake/dry root mass (Fageria, 1998); nitrogen utilization efficiency, NUtE $\left(\mathrm{g} \mathrm{g}^{-1}\right)=$ total plant dry mass/nitrogen content in the whole plant (Abbadi \& Gerendás, 2015); nitrogen physiological efficiency, NPE $\left(\mathrm{g} \mathrm{g}^{-1}\right)=$ (total plant dry mass with fertilization - total plant dry mass without fertilization)/ (accumulated nitrogen with fertilization - nitrogen accumulated without fertilization) (Fageria, 1998); recovery efficiency, RE $(\%)=$ (nitrogen accumulated with fertilization - nitrogen accumulated without fertilization)/applied nitrogen (Fageria, 1998); and biomass conversion efficiency, BCE $\left(\mathrm{g} \mathrm{g}^{-1}\right)=$ shoot dry matter mass/nitrogen in the shoot (Fageria, 1998).

A completely randomized design was used, in a $2 \times 3$ factorial arrangement (plant organ $\mathrm{x}$ nitrogen concentrations) with five plants per treatment for each species, totaling 60 plants. The nutritional efficiency indexes considered the plant organ and the concentration of nitrogen, and were analyzed using the multivariate ordination technique of non-metric multidimensional scaling (nMDS). The Euclidean distance metric index was used to analyze the two dimensions of the graph and considered stress $\leq 0.15$. The dissimilarity between groups was tested with the multivariate technique of one-way analysis of similarity (Anosim), at 5\% probability and with $\mathrm{R}<1$. The contribution of each nutritional efficiency index to the dissimilarity between groups was assessed through the multivariate analysis by similarity percentage. All variables were standardized using $\mathrm{z}$ transformation prior to the analysis. The analyses were performed with the Past, version 2.16, statistical software (Hammer et al., 2001).

\section{Results and Discussion}

The nitrogen indexes of $G$. lingulata and $V$. 'Harmony' were different when the nitrogen fertilizer was supplied to the plant roots or to the tank (Table 2). Both species, when fertilized in the tanks with 5.34 mmol L-1 nitrogen, showed the highest NUpE and RE averages. When they were root fertilized, with 2.62 $\mathrm{mmol} \mathrm{L}^{-1}$ nitrogen, they had the highest NUE, NUtE, NPE, and BCE averages.

The basal part of bromeliad leaves is mainly involved in nitrate reduction and urea hydrolysis, while the apical part predominantly assimilates ammonium through the action of glutamate synthase and glutamate dehydrogenase enzymes (Takahashi \& Mercier, 2011). Studies with epiphytic bromeliads (Benzing \& Renfrow, 1974; Winkler \& Zotz, 2009; Takahashi \& Mercier, 2011; Leroy et al., 2013) have designated the tank as the main organ responsible for nutrient uptake and assimilation. Interestingly, however, the present study showed that the roots of epiphytic bromeliads are not only functional for nitrogen uptake, but can also significantly contribute to the subsequent investment of the nutrient in biological processes, such as biomass increment, as shown by the NUE, NUtE, NPE, and BCE indexes.

The plant tanks showed higher nitrogen uptake and acquisition; however, they did not convert nitrogen into biomass as efficiently as the roots, as indicated by the other indexes measured. The nutrient consumption profile and nitrogen investment in tank-fertilized plants may reflect their adaptation to the natural

Table 1. Chemical composition of the pine bark used as substrate for the evaluated bromeliads.

\begin{tabular}{cccccccccccccccc}
\hline $\mathrm{N}$ & $\mathrm{P}_{2} \mathrm{O}_{5}$ & $\mathrm{~K}_{2} \mathrm{O}$ & $\mathrm{Ca}$ & $\mathrm{Mg}$ & $\mathrm{S}$ & Moisture & Organic matter & Carbon & $\mathrm{Na}$ & $\mathrm{Cu}$ & $\mathrm{Fe}$ & $\mathrm{Mn}$ & $\mathrm{Zn}$ & $\mathrm{C} / \mathrm{N}$ & $\mathrm{pH}$ \\
\hline 0.50 & 0.1 & - & 0.3 & 0.1 & 0.3 & 57.0 & 26.0 & 14.0 & 129 & 6 & 3677 & 52 & 13 & $28 / 1$ & 3.50 \\
\hline
\end{tabular}


environment. Epiphytic bromeliads, for example, are slow-growing plants, adapted to environments with low nutritional availability (Winkler \& Zotz, 2009; Benzing, 2015). Plants with these characteristics exhibit the ability to maximize nutrient uptake in habitats with highly-intermittent water and nutrient supply, a phenomenon that is termed "luxury consumption". The internal transfer of nutrients to growing organs during periods of insufficient supply may allow these bromeliads to maintain growth for a considerable amount of time (Winkler \& Zotz, 2009, 2010). The benefits of this selective pressure allow the continuous growth of bromeliads, even in the absence of nutrients. This feature can be used as a competitive attribute, minimizing competition with other plants for limited nutrients (Benzing \& Renfrow, 1974; Winkler \& Zotz, 2009; Mazancourt \& Schwartz, 2012). Remarkably, although the species selected for the present study are usually used as ornamentals, they retain characteristics formed by selection pressure in the natural environment.

Nitrogen supply in different vegetative organs probably triggers different physiological mechanisms to access the nutrient. Although the plants were fertilized with the same quantities of nitrogen in both organs, the roots proved to be highly efficient in the uptake of the element, although values of absorption and acquisition were higher in the tank. This might be explained by the fact that the tank has a more suitable morphology for water and nutrient uptake (Takahashi \& Mercier, 2011), which provides a direct and continuous contact between plants and the element. In addition, when the solution was applied to the substrate, it most likely became diluted by the time it reached the roots. It has been reported, for example, that more than $60 \%$ of nitrogen applied to the soil is lost by a combination of factors, such as leaching, denitrification, volatilization, immobilization, or microbial consumption (Kant et al., 2011). Moreover, substrates may pose a physical resistance to nutrient uptake (Baligar et al., 2001), when compared to tanks. Therefore, the NUpE in rootfertilized plants might not reflect a lower efficiency in nitrogen uptake, but rather an increased resistance to nutrient uptake caused by a small amount of nitrogen reaching the roots, in comparison with the tank.

Root-fertilized plants also showed a higher investment in biomass and photosynthetic area, as evidenced by NUE, NUtE, NPE, and BCE. Most carbohydrates are allocated to the development of new tissues, and a greater production of new leaves may ensure a decrease in the translocation of these compounds to the root system, reducing nitrogen uptake rates (Eissenstat, 2007; Brunetto et al., 2016).

Table 2. Means \pm standard deviation of nitrogen use efficiency (NUE), nitrogen uptake efficiency (NUpE), nitrogen utilization efficiency (NUtE), nitrogen physiological efficiency (NPE), recovery efficiency (RE), and biomass conversion efficiency (BCE) of the different vegetative organs (roots or tank) of the bromeliad species Guzmania lingulata and Vriesea 'Harmony', subjected to nitrogen fertilization with 2.62 or $5.34 \mathrm{mmol} \mathrm{L}^{-1} \mathrm{~N}$, as urea.

\begin{tabular}{|c|c|c|c|c|}
\hline \multirow[t]{2}{*}{ Variable } & \multicolumn{2}{|c|}{ Root } & \multicolumn{2}{|c|}{ Tank } \\
\hline & $2.62 \mathrm{mmol} \mathrm{L}^{-1} \mathrm{~N}$ & $5.34 \mathrm{mmol} \mathrm{L}^{-1} \mathrm{~N}$ & $2.62 \mathrm{mmol} \mathrm{L}^{-1} \mathrm{~N}$ & $5.34 \mathrm{mmol} \mathrm{L}^{-1} \mathrm{~N}$ \\
\hline \multicolumn{5}{|c|}{ Guzmania lingulata } \\
\hline NUE & $3.21 \pm 1.05$ & $1.95 \pm 0.36$ & $2.94 \pm 0.08$ & $1.50 \pm 0.05$ \\
\hline NUpE & $15.12 \pm 5.45$ & $9.14 \pm 5.37$ & $15.29 \pm 4.70$ & $23.13 \pm 14.53$ \\
\hline NUtE & $1.30 \pm 0.48$ & $1.32 \pm 0.22$ & $0.89 \pm 0.08$ & $0.68 \pm 0.09$ \\
\hline NPE & $0.08 \pm 0.05$ & $0.08 \pm 0.03$ & $0.01 \pm 0.04$ & $0.01 \pm 0.02$ \\
\hline $\mathrm{RE}$ & $7.41 \pm 3.39$ & $8.54 \pm 3.45$ & $10.54 \pm 1.73$ & $11.46 \pm 2.40$ \\
\hline $\mathrm{BCE}$ & $1.14 \pm 0.43$ & $1.08 \pm 0.10$ & $0.76 \pm 0.07$ & $0.59 \pm 0.06$ \\
\hline \multicolumn{5}{|c|}{ Vriesea 'Harmony' } \\
\hline NUE & $4.10 \pm 0.69$ & $2.08 \pm 0.24$ & $3.65 \pm 0.94$ & $1.91 \pm 0.65$ \\
\hline NUpE & $7.35 \pm 8.40$ & $3.40 \pm 0.59$ & $5.48 \pm 1.59$ & $9.81 \pm 4.34$ \\
\hline NUtE & $1.50 \pm 0.32$ & $1.40 \pm 0.16$ & $0.94 \pm 0.27$ & $0.76 \pm 0.27$ \\
\hline NPE & $0.07 \pm 0.06$ & $0.05 \pm 0.03$ & $0.02 \pm 0.05$ & $0.01 \pm 0.03$ \\
\hline $\mathrm{RE}$ & $9.12 \pm 2.72$ & $6.42 \pm 3.92$ & $17.97 \pm 9.82$ & $18.18 \pm 11.53$ \\
\hline $\mathrm{BCE}$ & $1.06 \pm 0.14$ & $0.98 \pm 0.16$ & $0.67 \pm 0.18$ & $0.57 \pm 0.22$ \\
\hline
\end{tabular}


The most efficient use of nitrogen for plant growth was observed in plants with roots fertilized with 2.62 $\mathrm{mmol} \mathrm{L}{ }^{-1}$, as shown by the higher averages of the NUE and BCE indexes. This result indicates that epiphytic plants can optimize a smaller amount of nitrogen supply in order to enhance biological processes. It should be noted that NUE indexes and their different parameters are commonly used to evaluate and compare genotypes of crop plants, such as corn (Zea mays L.), soybean [Glycine max (L.) Merr.], rice (Oryza sativa L.), and wheat (Triticum aestivum L.). Frequently, these species also have higher NUE values when they are cultivated with low concentrations of nitrogen (Kant et al., 2011; Franklin et al., 2017). Therefore, nutritional efficiency tends to decrease with increasing nutrient levels, as a result of diminishing returns in biomass production with the successive addition of the nutrient (Fageria, 1998).

Throughout the different parameters that constitute NUE, homogeneous groups in the multivariate analysis were observed. The nMDS for G. lingulata (Figure $1 \mathrm{~A}$ ) showed that the sampling units related to the roots were separated from those related to the tank, independently of the nitrogen concentration. However, the tank showed a better distinction between the groups due to its high nitrogen uptake capacity. The separation of groups, as presented by the nMDS diagrams, was significant at $0.1 \%$ probability $(\mathrm{R}=0.36)$, according to the Anosim. The nMDS diagram for Vriesea 'Harmony' (Figure $1 \mathrm{~B}$ ) showed that plants with roots fertilized with $5.34 \mathrm{mmol} \mathrm{L}^{-1}$ constituted the group with the longest distance from the other treatments. A small overlap was observed between plants fertilized with $2.62 \mathrm{mmol} \mathrm{L}^{-1}$ in the tank or through the roots. The dissimilarity between groups was significant at $5 \%$ probability, with $\mathrm{R}=0.33$.

The nMDS diagrams showed a homogeneous separation in terms of NUE, between roots and tank for both species. However, G. lingulata was more efficient than Vriesea 'Harmony' in nitrogen uptake, when comparing roots with the tank, suggesting that responses to nutrition may vary between species. Vanhoutte et al. (2017) reported higher nutrient and water uptake by Vriesea 'Splenriet' in the roots, compared with the tanks; however, Vriesea 'Galaxia' was more responsive than Vriesea 'Splenriet' to increases in the nutrient concentration in the tanks.
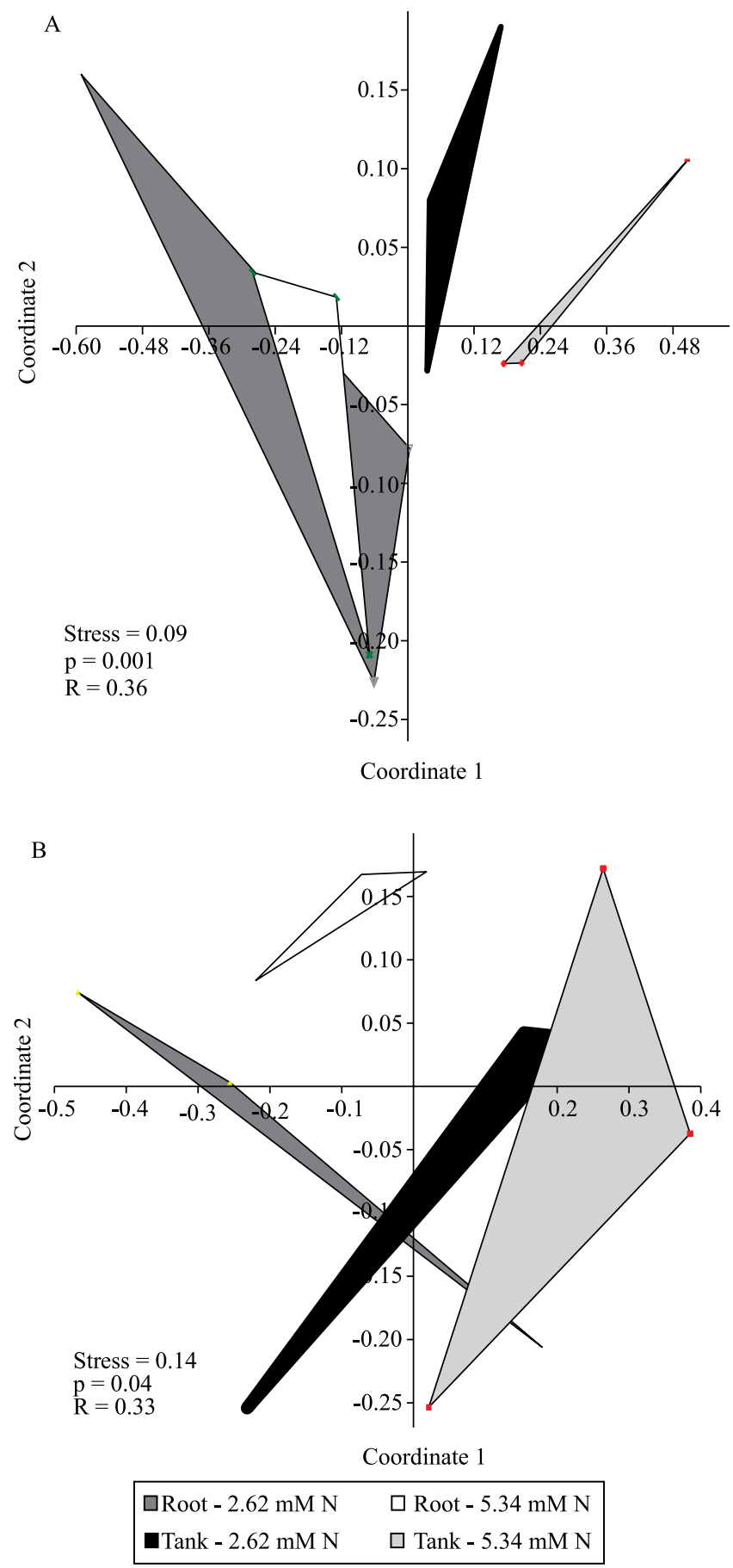

Figure 1. Diagram of non-metric multidimensional scaling (nMDS), considering the ordering of the groups formed by the fertilized organ (roots or tank) and by the concentration of nitrogen applied to the bromeliad species Guzmania lingulata (A) and Vriesea 'Harmony' (B). The stress value is the distortion between the actual data and that plotted in the diagram. The statistical inference of the dissimilarity among groups was obtained with the multivariate technique of oneway analysis of similarity, at $5 \%$ probability and with $\mathrm{R}<1$. 
In modern horticulture, knowing the factors that influence NUE is the key for improving the growth and development of cultivated bromeliads, avoiding the unnecessary use of fertilization and, consequently, preventing damage to the environment. The multivariate analysis showed that the indexes related to nitrogen investment in biomass (NUE, NPE, BCE, and NUtE) contributed the most to the dissimilarity between groups of G. lingulata, followed by the NUpE and RE indexes related to nitrogen uptake (Table 3). NUE, NUtE, and BCE showed the highest contribution to the dissimilarity between the groups of Vriesea 'Harmony'. However, NPE had a smaller contribution to the dissimilarity in Vriesea 'Harmony', compared with that in G. lingulata.

The present study showed that NUE parameters were effective in identifying the response capacity of the tank and roots to nitrogen fertilization and in evaluating the nutritional status of bromeliads. The obtained results suggest a new fertilization procedure for bromeliad management, in which root fertilization might be prioritized, since roots were functional for nitrogen uptake and had superior averages of NUE, NUtE, NPE, and BCE, compared with the tank.

Table 3. Multivariate analysis by similarity percentage for the relative contribution of the evaluated variables nitrogen use efficiency (NUE), nitrogen uptake efficiency $(\mathrm{NUpE})$, nitrogen utilization efficiency (NUtE), nitrogen physiological efficiency (NPE), recovery efficiency (RE), and biomass conversion efficiency (BCE) - to the dissimilarity observed between the groups formed by the fertilized organ (roots or tank) and by the concentration of nitrogen applied to the bromeliad species Guzmania lingulata and Vriesea 'Harmony'.

\begin{tabular}{lcc}
\hline Variable & Guzmania lingulata & Vriesea 'Harmony' \\
\hline NUE & 18.00 & 18.00 \\
NPE & 17.00 & 17.50 \\
BCE & 17.00 & 17.50 \\
NUtE & 17.00 & 16.00 \\
NUpE & 15.50 & 15.50 \\
RE & 15.50 & 15.50 \\
\hline
\end{tabular}

\section{Conclusions}

1. The root system of the epiphytic bromeliads Guzmania lingulata and Vriesea 'Harmony' is functional and significantly contributes to plant nutrition.

2. The tanks of the ornamental bromeliad species evaluated show greater uptake and acquisition of nitrogen than the root system; however, they do not convert nitrogen into biomass as efficiently as the roots.

3. The tank and roots of epiphytic bromeliads should be considered for the evaluation of nutrient uptake, and the indexes used in this study provide important parameters to guide fertilization management.

\section{Acknowledgments}

To Conselho Nacional de Desenvolvimento Científico e Tecnológico (CNPq), for support (project number 455929/2014-9) and productivity grant (number 306140/2012-8); and to Coordenação de Aperfeiçoamento de Pessoal de Nível Superior (Capes), for the post-graduate scholarship grant.

\section{References}

ABBADI, J.; GERENDÁS, J. Phosphorus use efficiency of safflower (Carthamus tinctorius L.) and sunflower (Helianthus annuus L.). Journal of Plant Nutrition, v.38, p.1121-1142, 2015. DOI: 10.1080/01904167.2014.983115.

ANACLETO, A.; NEGRELLE, R.R.B. Produção de bromélias no Estado do Paraná, Brasil. Ornamental Horticulture, v.19, p.121136, 2013. DOI: 10.14295/rbho.v19i2.421.

BALIGAR, V.C.; FAGERIA, N.K.; HE, Z.L. Nutrient use efficiency in plants. Communications in Soil Science and Plant Analysis, v.32, p.921-950, 2001. DOI: 10.1081/CSS-100104098.

BENZING, D.H. Vascular epiphytes in forest ecosystems. In: PEH, K.S.-H.; CORLETT, R.T.; BERGERON, Y. (Ed.). Routledge handbook of forest ecology. Abingdon: Routledge, 2015. p.198214.

BENZING, D.H.; OTT, D.W. Vegetative reduction in epiphytic Bromeliaceae and Orchidaceae: its origin and significance. Biotropica, v.13, p.131-140, 1981. DOI: 10.2307/2387715.

BENZING, D.H.; RENFROW, A. The mineral nutrition of Bromeliaceae. Botanical Gazette, v.135, p.281-288, 1974. DOI: $10.1086 / 336762$.

BRUNETTO, G.; CERETTA, C.A.; MELO, G.W.B. de; GIROTTO, E.; FERREIRA, P; COUTO, R. da R.; TASSINARIA, A.; HAMMERSCHMITT, R.K.; SILVA, L.O.S. da; LAZZARETTI, B.P.; KULMANN, M.S. de S.; CARRANCA, C. Contribution

Pesq. agropec. bras., Brasília, v.53, n.6, p.703-709, June 2018

DOI: 10.1590/S0100-204X2018000600006 
of nitrogen from urea applied at different rates and times on grapevine nutrition. Scientia Horticulturae, v.207, p.1-6, 2016. DOI: 10.1016/j.scienta.2016.05.002.

DETTKE, G.A.; MILANEZE-GUTIERRE, M.A. Anatomia vegetativa de Bromelia antiacantha Bertol. (Bromeliaceae, Bromelioideae). Balduinia, v.13, p.1-14, 2008. DOI: 10.5902/2358198014050.

DOVALE, J.C.; FRITSCHE-NETO, R.; BERMUDEZ, F.; MIRANDA, G.V. Efeitos gênicos de caracteres associados à eficiência no uso de nitrogênio em milho. Pesquisa Agropecuária Brasileira, v.47, p.385-392, 2012. DOI: 10.1590/S0100204X2012000300010.

EISSENSTAT, D.M. Dinamica di crescita delle radici nelle colture da frutto. Italus Hortus, v.14, p.1-8, 2007.

FAGERIA, N.K. Otimização da eficiência nutricional na produção das culturas. Revista Brasileira de Engenharia Agrícola Ambiental, v.2, p.6-16, 1998. DOI: 10.1590/1807-1929/agriambi. v02n01p6-16.

FAGERIA, N.K. The use of nutrients in crop plants. Boca Raton: CRC Press, 2009.

FRANKLIN, O.; CAMBUI, C.A.; GRUFFMAN,L.; PALMROTH, S.; OREN, R.; NÄSHOLM, T. The carbon bonus of organic nitrogen enhances nitrogen use efficiency of plants. Plant, Cell \& Environment, v.40, p.25-35, 2017. DOI: 10.1111/pce.12772.

GIAMPAOLI, P.; SANTOS, D.S. dos.; MOLLO, L.; KANASHIRO, S.; TAVARES, A.R. Effect of fertilisation with urea on development in the ornamental bromeliad Aechmea fasciata. Revista Ciência Agronômica, v.48, p.657-662, 2017. DOI: $10.5935 / 1806-6690.20170076$.

GONÇALVES, A.Z.; MERCIER, H.; OLIVEIRA, R.S.; ROMERO, G.Q. Trade-off between soluble protein production and nutritional storage in Bromeliaceae. Annals of Botany, v.118, p.1199-1208, 2016. DOI: 10.1093/aob/mcw174.

HAMMER, Ø.; HARPER, D.A.T.; RYAN, P.D. PAST: paleontological statistics software package for education and data analysis. Palaeontologia Electronica, v.4, art.4, 2001.

HIREL, B.; TÉTU, T.; LEA, P.J.; DUBOIS, F. Improving nitrogen use efficiency in crops for sustainable agriculture. Sustainability, v.3, p.1452-1485, 2011. DOI: 10.3390/su3091452.

HOAGLAND, D.R.; ARNON, D.I. The water-culture method for growing plants without soil. Berkeley: California Agricultural Experiment Station, 1950. 32p.

KANT, S.; BI, Y.-M.; ROTHSTEIN, S.J. Understanding plant response to nitrogen limitation for the improvement of crop nitrogen use efficiency. Journal of Experimental Botany, v.62, p.1499-1509, 2011. DOI: 10.1093/jxb/erq297.
LAUFER, D.; NIELSEN, O.; WILTING, P.; KOCH, H.-J.; MÄRLÄNDER, B. Yield and nitrogen use efficiency of fodder and sugar beet (Beta vulgaris L.) in contrasting environments of northwestern Europe. European Journal of Agronomy, v.73, p.124-132, 2016. DOI: 10.1016/j.eja.2015.11.008.

LEROY, C.; CARRIAS, J.-F.; CORBARA, B.; PÉLOZUELO, L.; DÉZERALD, O.; BROUARD, O.; DEJEAN, A.; CÉRÉGHINO, R. Mutualistic ants contribute to tank-bromeliad nutrition. Annals of Botany, v.112, p.919-926, 2013. DOI: 10.1093/aob/mct147.

LÜTTGE, U. Ability of crassulacean acid metabolism plants to overcome interacting stresses in tropical environments. AoB Plants, v.2010, plq005, 2010. DOI: 10.1093/aobpla/plq005.

MALES, J. Think tank: water relations of Bromeliaceae in their evolutionary context. Botanical Journal of the Linnean Society, v.181, p.415-440, 2016. DOI: 10.1111/boj.12423.

MAZANCOURT, C. de; SCHWARTZ, M.W. Starve a competitor: evolution of luxury consumption as a competitive strategy. Theoretical Ecology, v.5, p.37-49, 2012. DOI: 10.1007/ s12080-010-0094-9.

NORTH, G.B.; LYNCH, F.H.; MAHARAJ, F.D.R.; PHILLIPS, C.A.; WOODSIDE, W.T. Leaf hydraulic conductance for a tank bromeliad: axial and radial pathways for moving and conserving water. Frontiers in Plant Science, v.4, art.78, 2013. DOI: 10.3389/ fpls.2013.00078.

SILVA, I.V. da; SCATENA, V.L. Anatomia de raízes de nove espécies de Bromeliaceae (Poales) da região amazônica do estado de Mato Grosso, Brasil. Acta Botanica Brasilica, v.25, p.618627, 2011. DOI: 10.1590/S0102-33062011000300015.

TAKAHASHI, C.A.; MERCIER, H. Nitrogen metabolism in leaves of a tank epiphytic bromeliad: characterization of a spatial and functional division. Journal of Plant Physiology, v.168, p.1208-1216, 2011. DOI: 10.1016/j.jplph.2011.01.008.

VANHOUTTE, B.; SCHENKELS, L.; CEUSTERS, J.; DE PROFT, M.P. Water and nutrient uptake in Vriesea cultivars: trichomes vs. roots. Environmental and Experimental Botany, v.136, p.21-30, 2017. DOI: 10.1016/j.envexpbot.2017.01.003.

WINKLER, U.; ZOTZ, G. 'And then there were three': highly efficient uptake of potassium by foliar trichomes of epiphytic bromeliads. Annals of Botany, v.106, p.421-427, 2010. DOI: 10.1093/aob/mcq120.

WINKLER, U.; ZOTZ, G. Highly efficient uptake of phosphorus in epiphytic bromeliads. Annals of Botany, v.103, p.477-484, 2009. DOI: $10.1093 / \mathrm{aob} / \mathrm{men} 231$.

XU, G.; FAN, X.; MILLER, A.J. Plant nitrogen assimilation and use efficiency. Annual Review of Plant Biology, v.63, p.153-182, 2012. DOI: 10.1146/annurev-arplant-042811-105532.

$\overline{\text { Received on November 12, } 2016 \text { and accepted on August 31, } 2017}$ 